\title{
A CLINICAL STUDY OF THE DIAGNOSIS OF OLFACTORY DISTURBANCE BY MEANS OF A STANDARD OLFACTORY ACUITY TISST
}

\author{
SEIKO OYAIZU, M.D. \\ Department of Oto-Rhino-Laryngology, School of Medicine,
}

Showa University, Tokyo

(Director: M. Okamoto, M.D.)

A standard olfactory acuity test was performed on 296 patients with olfactory disturb. ances. These patients were classified into 4 groups, based on clinical examinations including anterior rhinoscopy, X-ray examination, intravenous olfaction test by alinamine and observation of the olfactory epithelium by selfox endoscopy. These groups were; Group A, with respiratory olfactory disturbance ( 9 cases), B, with epithelial olfactory disturbance ( 75 cases), C, with combined olfactory disturbance (184 cases), and D, with central olfactory disturbance (28 cases). In addition, 32 normal subjects with anterior nasal packings by small cotton filters were also examined as Group, E, having artificial respiratory olfactory disturbance.

The results were as follows:

1) The detection threshold and the recognition threshold were scaled out in more than $50 \%$ of $\mathrm{B}, \mathrm{C}$ and $\mathrm{D}$ groups. In $\mathrm{A}$ and $\mathrm{E}$ groups, there was an elevation in both thresholds.

2) There was no conceivable difterence in the threshold for the 5 standard odors ( $\beta$-phenyl ethyl alcohol, iso-valeric acid, methyl cyclopentenolone, $\gamma$-undecalactone and scatol) in each case.

3) The difference between the detection and the recognition thresholds in Group $E$ was under the level of 2, i.e., witlin the range of normal variation, A similar result was obtained in Group A. However, the difference was larger in B, C and D groups.

4) The cause of respiratory olfactory disturbance in group $A$ was considered to be due to the disturbance of air flow to reach the olfactory area, while in group $\mathrm{E}$, it should be due to the disturbance to reach the entire nasal cavity. Thus, the difference in the threshold between $\mathrm{A}$ and $\mathrm{E}$ must originate from the condition whether the odors reaches only the olfactory area or the entire nasal cavity.

5) The difference in the threshold between A, E groups and B, C, D, groups was considered to be due to whether the perception of odors at the olfactory area was normal.

6) It was assumed that the detection threshold was related to the perception at other parts of the nasal cavity than the olfactory area.

By using the standard olfactory acuiy test, topical diagnosis of olfactory disturbance can be easily conducted. 
A $81-0780-30522$

\title{
基準嗅力検査法による嗅覚障害診断への臨床的応用
}

\author{
昭和大学医学部耳鼻咽喉科学教室 (主任 : 岡本途也教授)
}

小柳津 聖 子

\section{I 緒 言}

近年日常生活の多様化とともに, 生活を楽しむ傾向が 高まり，それにともない嗅覚への関心も高まった。しか しながら嗅覚の本態は勿論, 噴覚障害の実態はいまだ不 明な点が多いこれらを解明するため, 統一された嗅覚 検查法の確立が望まれていた。 昭和 46 年文部省科学研究 費「嗅覚測定のための基準臭と検查方式の研究」班 ${ }^{1}$ に おいて，嗅賞測定のための基準10臭が決定された，その 後,この内の 5 種を基準臭とし，これを用いて臨床的に 嗅覚検查をする基準嗅力検查法 ${ }^{2}$ が決定された：この検 査装置を T\& $\mathrm{T}$ オルファクトメータといら。これを隐 床的に応用した嗅覚障害者の詳細なデータはいまだ報告 されていないので，著者は㖵覚障害者に対し， T \& T オルファクトメータを用いた基準嗅力検查を施行し，嗅 覚障害者の嗅力の病態を検討したので報告する.

\section{II 研究方法}

1. 研究対象 昭和50年 1 月より12月までに昭和大学 病院耳鼻咽喉科㖵覚外来を訪れた嗅覚障害者 296 例，お よび嗅覚正常者32例を研究対象とした。

被検者に対し，1）前鼻鏡検査，2）顔面レントゲン 検查，3）アリナミン静脈試験，4）セルフォスコープ 針状硬性鏡検查 ${ }^{3}$ ，を施行し，この検査をもとに嗅覚障 害者を以下に示すごとく 4 群に分類した(表 1 ).

A群：呼吸性嗅覚障害群 $\cdots$ 何らかの原因で嗅素が嗅粘 膜に到達しないために起ったと考えら机る嗅覚障害…9

表 1 嗄党障害別の症例数

\begin{tabular}{|c|c|}
\hline 障害部位 & 症例数 \\
\hline A 群 呼吸性嗅覚障害 & 9 \\
\hline B群 嗅上皮性嗅覚障害 & 75 \\
\hline C群＼cjkstart混合性嗅覚障害 & 184 \\
\hline D群 中枢性嗅覚障害 & 28 \\
\hline E群 実験的呼吸性嗅賞障害 & 32 \\
\hline 計 & 328 \\
\hline
\end{tabular}

例

B群：嗅粘膜性嗔覚障害群・㖵粘膜が障害されたため に起ったと考えられる嗅覚障害…75例

C群：混合性嗅覚障害群 $\cdots A$ 群と B 群の原因が同時に 混在して起ったと考えられる嗅覚障害…184例

$\mathrm{D}$ 群：中枢神経性嗅覚障害…嗅采，嗅球打上びそれ以 上の中枢が障害されたと予想される嗅覚障害 ...28例

である。ささらに，嗅覚正常者に実験的に咱覚障害を生せ しめ

$\mathrm{E}$ 群：実験的呼吸性嗅賞障害群…前記の諸検查に全く 異常を認めず，さらに自覚的にも嗅覚の異常を訴えない 嗅賞正常者に乾燥した無臭の綿球を鼻前庭部に軽く挿入 し，実験的に起こさせた呼吸性嗅覚障害…32例 とした。

2. 基準嗅力検查 $\mathrm{T} \& \mathrm{~T}$ オルファクトメータを使 用した，検查法注班研究の決定にしたがって，検知域值 は被検者が何んらかの二オイを感じた嗅素の濃度番号を い，認知域值は各嗅素の特徵あるニオイを正しくいい 当てた場合の嗅素の濃度番号をいう。しかし，症例によ っては吉田の分類" ${ }^{4}$ 参考に適宜誘導し，認知域值の決 定を行った.

これらの測定は全例すべて著者自身が行い，測定した 検知域值, 認知域值をオルファクトグラム上に記載し た.

検査室は比較的換気の良い $125 \mathrm{~m}^{8}$ の部屋を用い，さ らに DALTON 製 erlab 型脱臭装置をせットし，T\& Tオルファクトメータから発する真気による室内の空気 の污染を防止した。

III 成 績

1. $\mathrm{A} \sim \mathrm{E}$ 群の代表的症例のオルファクトグラム

図 1 は $\mathrm{A} \sim \mathrm{E}$ 群の代表的な症例 $\mathrm{a}, \mathrm{b}, \mathrm{c}, \mathrm{d}, \mathrm{c}$, のオルファクトグラムである。症例 a (呵吸性嗅覚障害) は，検知域值は正常者のそれよりも上昇を示しているが 検知域値と認知域值の差は小さく, 認知城值はスケール アウトしていない。症例b（嗅粘膜性嗅覚障害）は，検 知城值江ほぼ正常者に近い値を示しているが，認知域値 


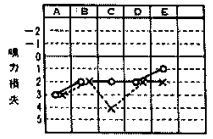

源倒了(A 群)

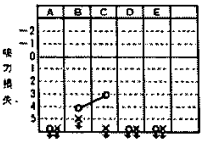

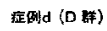

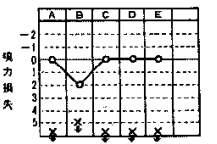

痘例b (B E)

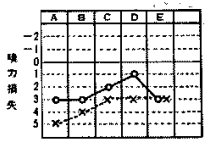

症㑬 $(E$ 强)

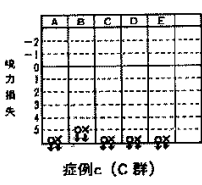

0-0 核知城值

$\times \cdots \times$ 知域值

図 $1 \mathrm{~A} \sim \mathrm{E}$ 群の代表的症例のオルファクトグラム
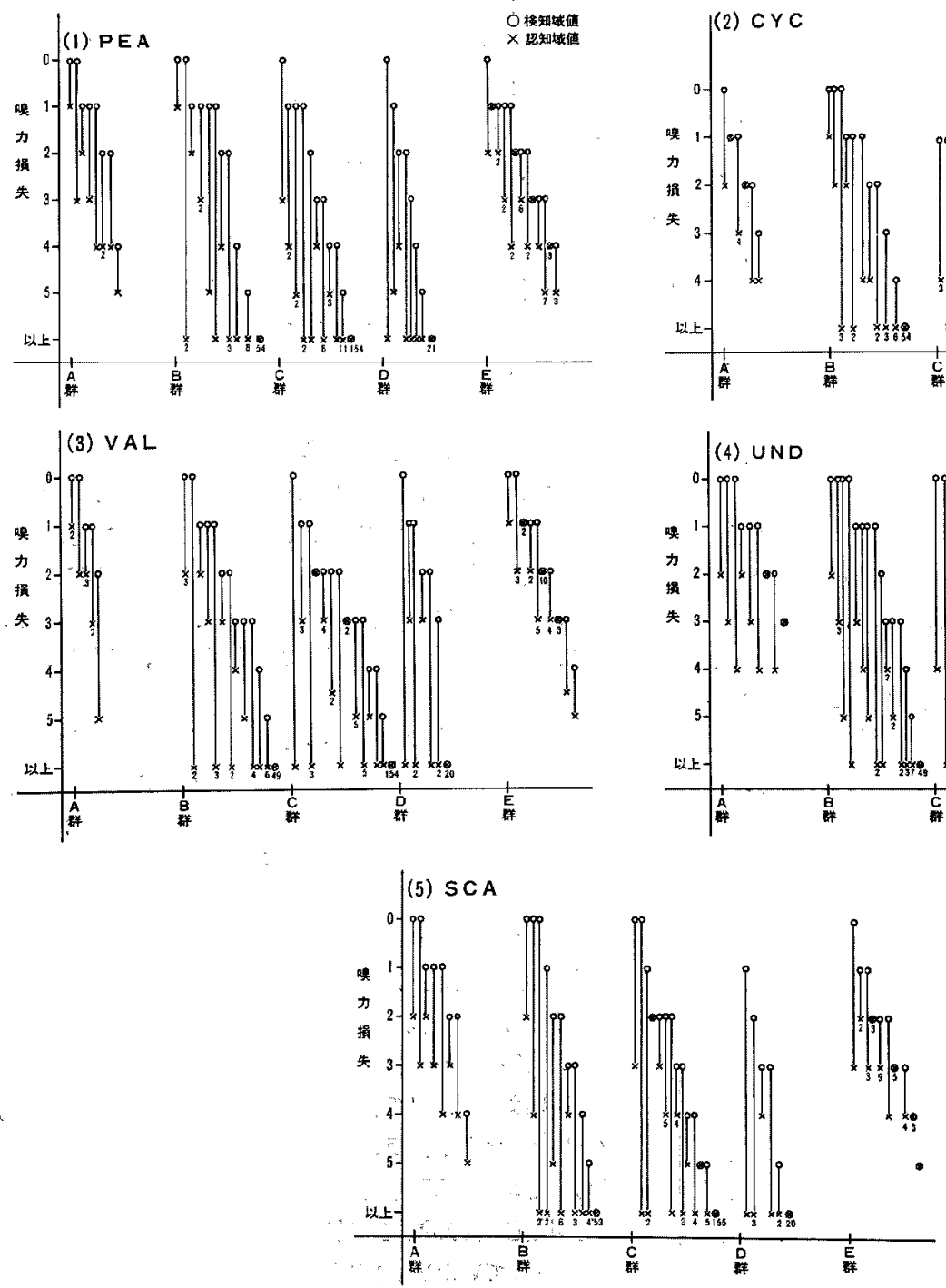

図 2. A E 群の症例数 
知域值を示した. 縦軸に嗅力損失, 横軸に各群をとり, 図中の○は検知域值, メは認知域值を示す 検知域值, 䛌知城值がスケールアウトした場合には以上の部に記し た. メの下の数字は，この表示に該当する症例数を示し $\hbar$.

図 3 亿各群の各嗅素ごとの検知域值と認知域值を集計 して示した. 横軸に各群をとり, 緃軸に嗅力損失を示 す. 図中の実線は検知域值の分散の中央 $7 / 8,87.5 \%$ が 占める幅を示し，破線は認知域值の分散の中央 $7 / 8,87.5$
\%が占める幅を示す， B， C，D群では，検知域值，認 知域值ともにスケールアウトした症例が多く，その分散 を図示することが困難であるので，限界点がスケールア ウトであったものは以上の部に記し，スケールアウト症 例数を下段に全例に対する百分率で表記した。

$\mathrm{A}, \mathrm{E}$ 群では各㖵素とも検知域值と認知城値のスケー ルアウトする症例は 1 例をなく， $\mathrm{B} ， \mathrm{C} ， \mathrm{D}$ 群にはかな りの症例に域值がスケールアウトしていた，B，C，D 群間では，検知域值については $\mathrm{B}$ 群が C, D群よりも嗅
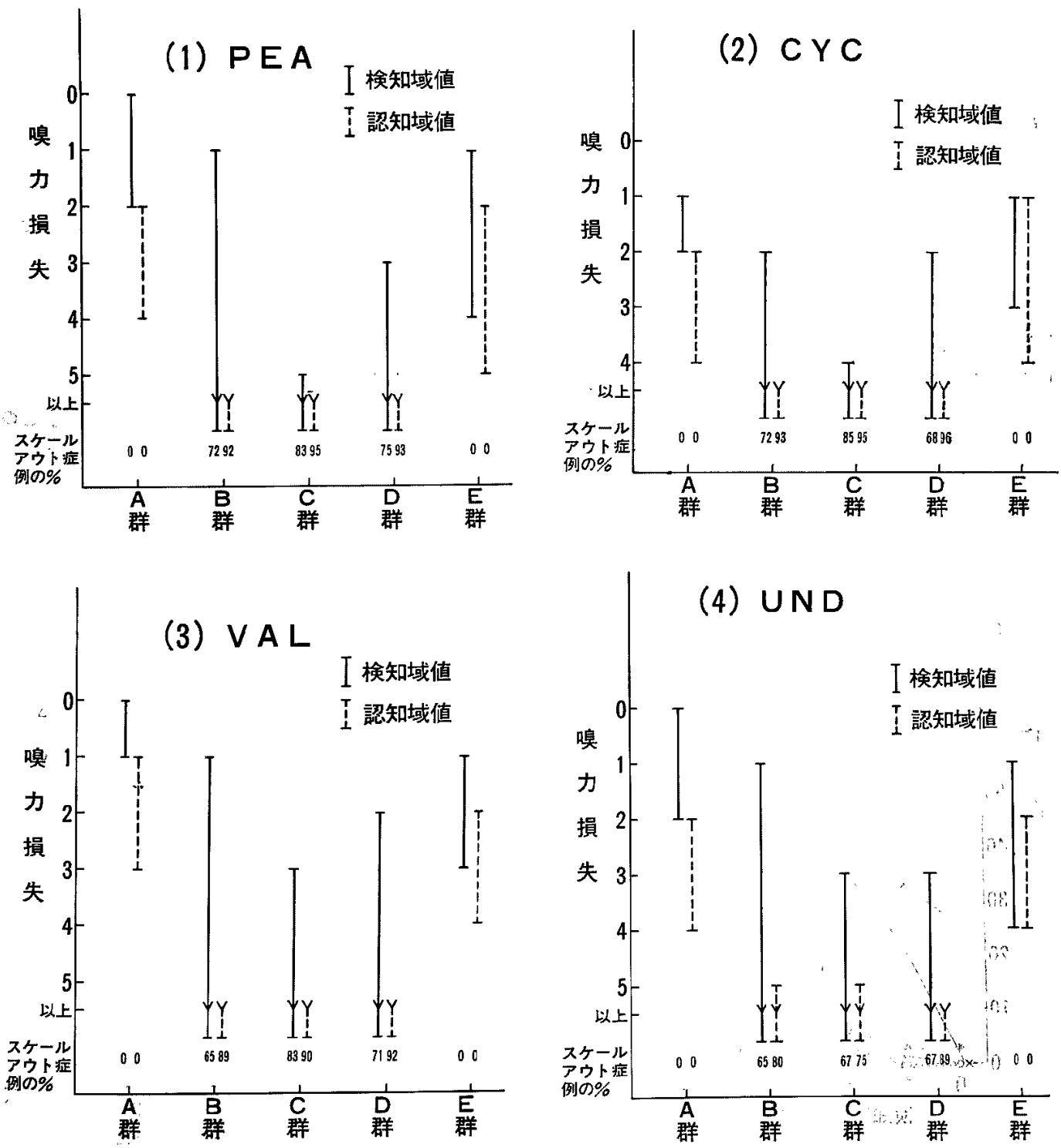


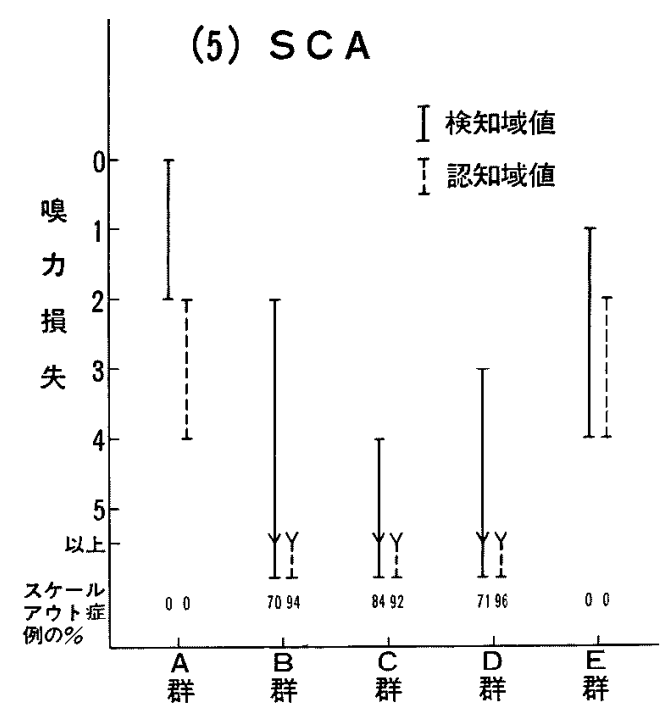

図 $3 \mathrm{~A} \sim \mathrm{E}$ 群の検知・珰知域值の分散

力損失の軽度なものが多く、C群が最も高度であった。 認知域值については，B，C，D群之施域值がスケール アウトしてしまうため，差の判定はできなかった。ま た，基準臭の.5 嗅素おのおのについて各群の嗅覚障害の

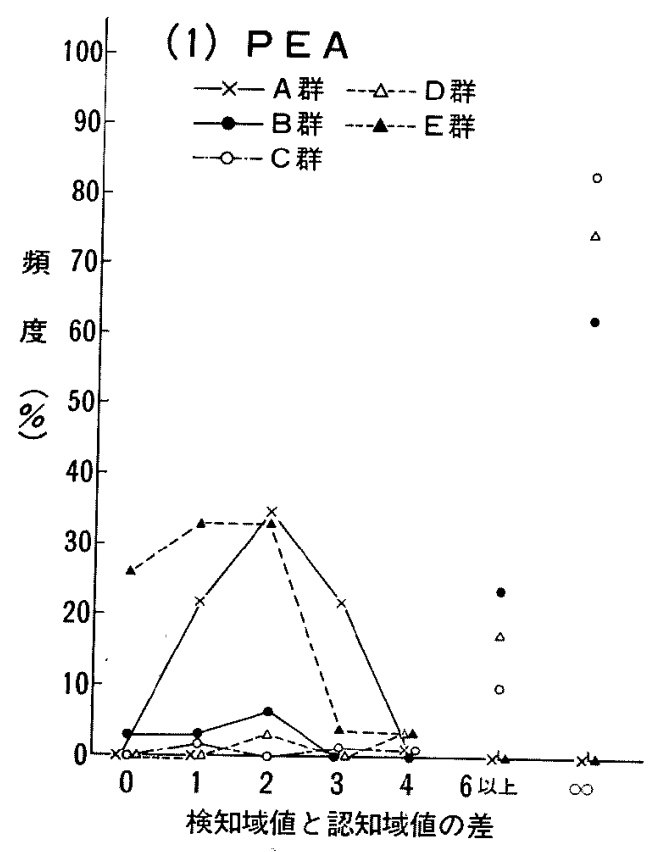

分布には，(2)CYCにてやや低い価を示吉他は本翼的な 差は認めなかった。

3. 検知域值亡認知域值の差の煩度分布

症例ごとに各嗅當に対する検知域值と認知域值との差

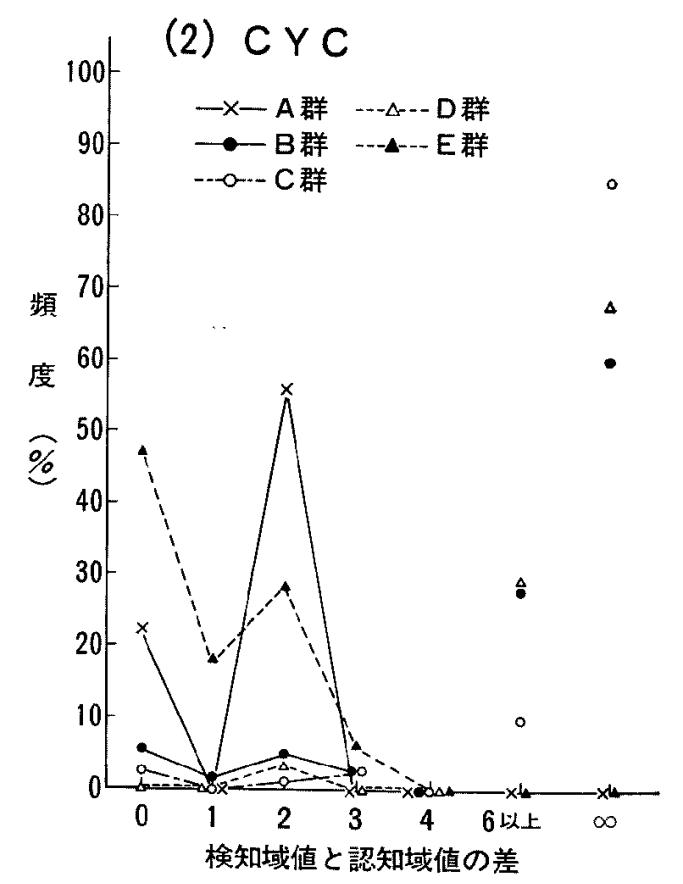



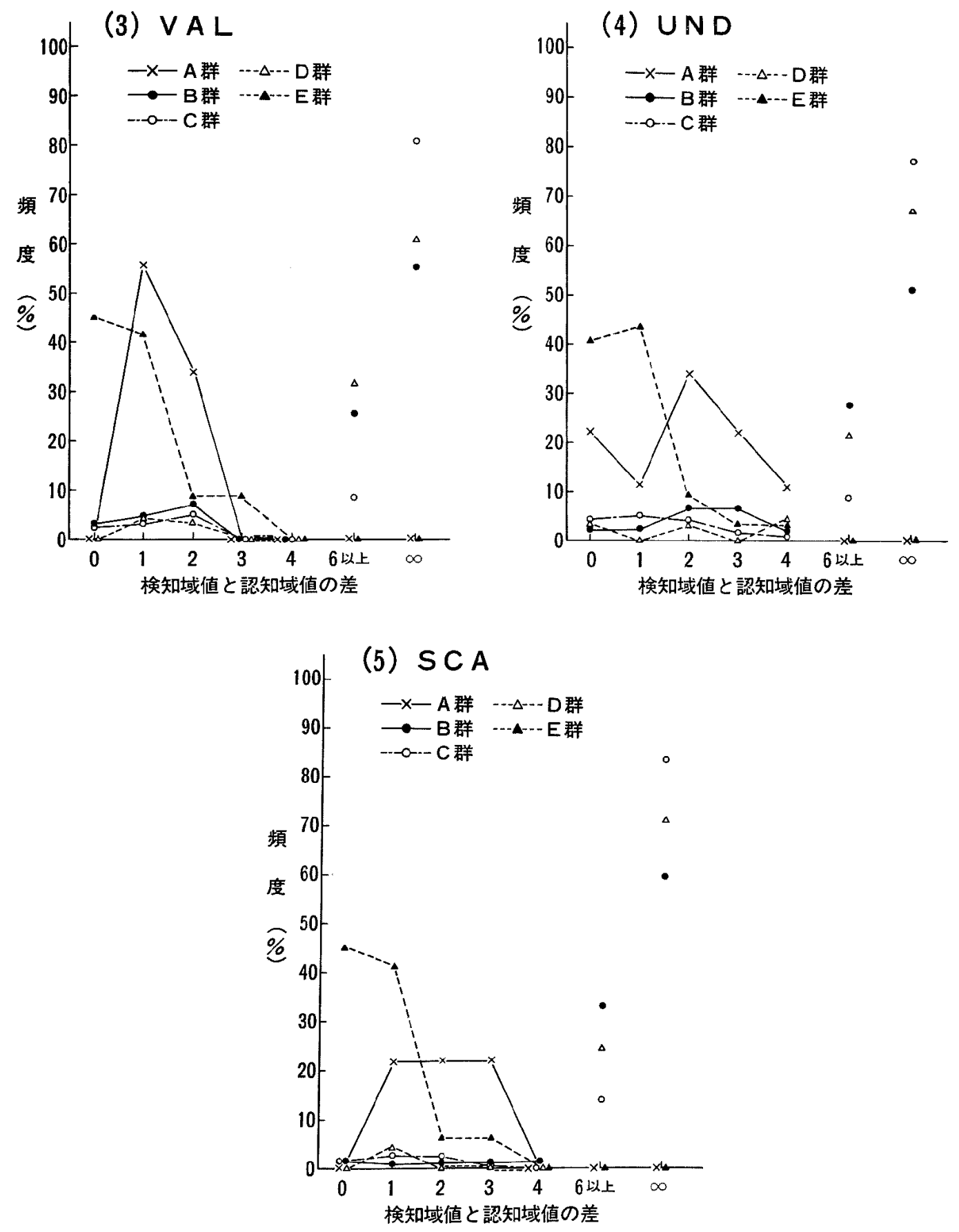

图 4 各群に垊ける検知域值と認知域值の差 の頪度分布 
を求め，その值の分布を各群ごとに集計した(図 4)，検 知域値七認知域值が判定されている時には差を求めるこ とは容易であるが，検知域值は測定されたが認知域值は スケールアウトしている場合にはその差を求めることが できないので，これを “6”とし，検知域值も認知域值も 測定できない場合にもその差を求めることができないの で“の”で表示した。

いずれの嗅素におるても $\mathrm{B} ， \mathrm{C} ， \mathrm{D}$ 群は類似の頻度分 布を示し，A，E群のそ叔とはまったく異っている。す なわち $\mathrm{B} ， \mathrm{C}, \mathrm{D}$ 群では検知，認知域值がともにスケー ルアウトしたため域值の差を求められない症例がいずれ の搝素についても半数以上を占めていた，そして心はC 群が最も多かった。

$\mathrm{A}, \mathrm{E}$ 群を比較すると，検知域値と認知域值の差のな い0は $\mathrm{E}$ 群に多く、2〜3はA群がやや多かった、A群 の症例数がやや少ないので断定はできないが，嗅素間の 差は明らかではなかった。

\section{IV 考按}

基準嗅力検查法を用いて嗅力検查を行った研究は，塩 $川^{55}$ により㖵覚正常者の嗅覚域值の年令的分布の検討は なされているが，嗅覚障害者に対寸る臨床的な検討に関 しては末解明な問題が多い。

1. 検知域值々認知域值測定上の問題

域值の判定に際し，㭘知域值は鮕素により刺激された 時に被検者が「何か」を感ずると応答した時の值であ る. 正しく「ニオイ」としてとらえていない場合でも， 検知域值上して判定される。故に，検知域值は被検者の 応答をそのまま域值とすればよいしかし，認知域值は 嗅素を被検者がその「ニオイよして感ずると応答した 時の值である. 正しく「ニオイ」としてとらえていなけ れば応答できない，その被検者の応答を検者は正しく 「ニオイ」として感してているか否かを判断しなければな らない，故に，認知域值の判定には検者の主観が入る可 能性がある、基隻 5 臭については，PEA; 花の「ニ才 イ」, CYC; 焦げた「ニオイ」, VAL; 腐敗の「ニオイ」, UND; 果実の「ニオイj, SCA; 蕒の「ニオイ」, 上さ れているが，各被検者が「ニオイとして感したその表 現は被検者の知識, 生活様式, 環境によりさまざをであ る.たとえば，CYCを焦げた「ニオイ」と決められて いるが，たくわんずけ，たまりしよう油，むむし酒な と，各嗅素の表現の籁眼以外の被検苩の応答を正しく判 定しなければならない，そのために，各嗅素の特徽ある 「ニオイ」の表現法を把握し，時には適切な誘遵を被検
者に与えることが必要なこともある，

2. 検知域值, 認知域值について

正常者の検知域值, 認知域值については, 塩川 ${ }^{(5)}$ の報 告がある，それによると基準 5 臬の検知域值は, 加令的 要素を考慮しても嗅力損失ー $1 \sim 2$ であり, 認知域値は

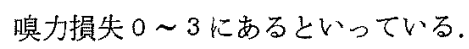

A群すなわち呼吸性嗅覚障害群では, 検知域値は 0 2 にあり, 認知域值は $2 \sim 4$ にある. 各嗅素別に検討し てみると呼吸性嗅営障害の检知抢上び認知域值は正常者 よりむ上昇しているが，その上昇の度は少ないままた呼 吸性嗅覚障害全例にて検知, 認知域值のスケールアウト するものは認められなかった，B群すなわち嗅粘膜性嗅 覚障害の検知域值は, 嗅力損失軽度のものよりスケール アウトまで幅広く存在している。認知域值は，高度㖵力 損失，スケールアウトを示しているむのが多い．C群す なわち混合性嗅覚障害群ではB群より検知, 認知域值は 上昇して扔り，スケールアウトした症例が多、．C群は 嗅粘膜性嗅覚障害に呼吸性嗅覚障害加加ったと考えられ る障害群であるので，B群よりもさらに域值が上昇して いるのは当然であるう。D群は中枢性嗅覚障害群で, 検 知，認知域值はB群と同様かまたはそれよりも上昇して いる.

3. 検知域值と認知域值との差

正常者の検知域值と認知域值との差は塩川によると 1 〜2である. A群についてみると, 検知域值と認知域值 との差はほとんどが 2 で $〜 4$ の範团をこえることはな い，各個人についてみるとこの差は正常者よりやや広い が，その差は著明ではない B群についてみると，検知 域値と認知域值の差は大となり，正常者およびA群とは ことなる．ただし認知域值のスケールフウトする例が多 くなるので，測定不能例が多くなる，C，D群は B群に 類似した傾向を認め，検知域值と認知域值の差が大であ るが，検知域值のスケールアウトする例がさらに多くな るので，両域值の差を求めることができないものが多 w

\section{4. 実験的呼吸性嗅覚障害}

E群すなわち実験的呼吸性嗔觉障害群とは, 正常者の 鼻前庭部に綿球を挿入することにより実験的に呼吸障害 を起こさしめたものである．完全な鼻入口部の閉鎖では なく，鼻呼吸は可能であるが制限される状態にしたの で，嗅索が鼻粘膜に到達する量は制限されていると考え られる。その結果, 当然ではめるが，検知，認知域值は 上界する。しかし，認知域值がスタールアウトする症例 
は認められなかった。

\section{E群の検知域值と認知域值との差}

$\mathrm{E}$ 群の検知域値と認知城值の差は正常者とほぼ同様で あったＡ群の差よりも小さい傾问を示した。この理由 は正常者に対する呼吸障害では綿球を通過して入った嗅 素は容易に䫝部へ達することができることを示している ものと考える，すなわち，群の人工的嗅覚障害は正常者 に濃度の薄い嗅覚で刺激したと同様であり，正常者の㖵 力の平行移動であると考えられる。

A群の嗅営障害は嗅部へ嗅素を送る通路の障害であ る．E群は鼻腔全体八嗅素を送る通路の障害である．嗅 部だけと鼻腔全体とに嗅素を送ることの差により，A群 の方が $\mathrm{E}$ 群より検知域值と諗知域值の差が大きいのでは ないかと推考される。しかしながら $\mathrm{E}$ 群注明らかにB， $\mathrm{C} ， \mathrm{D}$ 群の域值差と異って括り，単独に呼吸性要素に より嗅覚が障害された群と，嗅粘膜およびそれより中枢 側が障害された群とでは嗅覚に差があると考えられる。

6. 障害部位による嗅覚の差について

噚覚の検知域值と喼知域值扝よびその差をみるとA， $\mathrm{E}$ 群と $\mathrm{B} ， \mathrm{C}$ ， D群とでは明らかな差を認める。その原 因はA，E群では嗅粘膜へ嗅素が達するまでの物理的要 因と考えられ，B，D群では嗅粘膜以上の病態生理学的 現象上考えられる．C群では両原因が混在しているもの と考えられる．聴覚障害との類似性を求めるならば， $\mathrm{A}$ 法音難聴であり，B，Dは感音難聴，Cは混合難聴と 考它るのが妥当であるう。

物理的要因によるものでは検知域值と認知域值は平行 して低下するが，病態生理学的現象では域值は平行して 低下するとは限らないそのため，検知域值と認知域値 との差が 2 以上であれば，物理的要因のみの搝覚障害と は考えられない。

治療により嗅賞障害が治瘾したもの検討寸ると，A 群と B，C，D群とで㳉らかな差が認めら机る。才な わち， $\mathrm{A}$ 群は最も治療効果が高く，全例が短期間に軽快 ～全快する， B， C，D群治治痹与るもの，長期間かか って徐々に治凌するもの，まったく治療に反応を示さな いものに分けられるき， B，C，D群で嗅賞が改善され る場合のオルファクトグラムは，まず検知城值が正常に 近づき，次に認知域值が次第に正常に向5。これらの5 ちには，オルファクトグラム上で検知，珰知域值ともに スケールアウトしていてむ治痖する症例があるが，検知 域值が正常に近くしかも認知域值が高度嗅力損失〜スケ 一ルアウトしている症例ではまったく治療に反応を示さ
ないものが多い、検知域值が低いから治療効果があると は断定できないての理由について考按してみる。

検知，認知域值ともにスケールアウトしている場合 は，搝細胞を含む㖵神経が退化，消失しているものや嗅 紐胞の可逆的障害に強、呼吸性障害が加ったものがある と考劣られる、検知城值は測定できるが，諗知域值がス ケールアウトしている例ではまだ嗅細胞は完全に消夫し ていないと考えるのが妥当である5。しかし，検知域值 は嗅索が提示される時に何らかの異常を感じた場合の域 值であるから，認知域值がスケールアウトしている場合 の検知域值は嗅紐胞の反応と即断することは危険であ る。广和台，三文神経や舌㸶神経の末梢受容器が刺激 されるなど副嗅覚系 ${ }^{8}$ の反忘も考皮しなければならな い故に嗅細胞の可逆的な高度の障害によって検知域 值，認知域值がスケールアウトしている場合には治療に 反応するが，唄細胞が不可逆的な高度の障書を受け，認 知域值が測定できなくなったものでも副嗅覚采の反応に て検知域值が測定てきた場合には，治療に反応しないと 考えられる。

副嗅覚采の受容器は鼻腔のみならず, 咽頭, 口腔にも あるといわれている。A群と E群における検知域值, 認 知域值とその差がやや異るのは，この系の反応も考えら

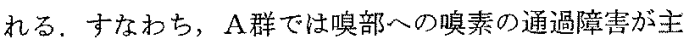
でり，E群のように鼻腔全体への通過障害上りも副嗅 覚系への刺激が容易と考えられる。しかし，A群の場合 には嗅粘膜が全く正常でない症例多あると推定されるの で注意を要する。

以上より基準嗅力検査法のみを用いての嗅覚障害部位 診断93は，呼吸性嗅鸴障害と嗅粘膜性嗅覚障害の有無に ついてはある程度可能であると思われる。しかしなが ら，昭和大学病院耳舅咽喉科嗅覚外来を訪孔る嗅覚障害 者抢よび嗅覚脱失者を対象としているため，臨床上最む 多い上推定される慢性副鼻腔炎や慢性鼻炎などの軽度の 隕覚障害が等闑視された傾向がある。今後，さらに詳細 な研究を進める必要がある。

\section{$\mathrm{V}$ 結論}

基準嗅力検査法用いての嗅覚障害者に対する䠦床的 研究はまだない，著者は嗅觉障害者を前鼻鏡険査，顔面 レントゲン検査，アリナミン静脈試験，七ルフォスコー プ針状硬性鏡検查により，呼吸性嗅覚障害，嗅粘膜性喚 敩障害，混合性嚊覚障害，中枢性嗅覚障害および，実歌 的呼吸性嗅覚障害の5 群に分け基準嗅力䄼查結果を検討 L坛. 
1) 嗅粘膜性, 混合性㧍よび中枢性㖵覚障 害 群の検 知, 認知域值は上昇し，スケールアウトした症例が半数 以上を占めた。 しかし, 呼吸性, 奏験的呼吸性嗅覚障害 群では, 各域值の上昇は認めるがその程度は低く，スケ ールアウトした症例はなかった。

2）基準 5 種嗅素間の嗅力損失の差は，障害部位別に て特徽的な変化を認めなかった。

3）嗅覚障害部位別に検知域值と認知域値の差をみる と，呼吸性拉よび実験的呼吸性嗅覚障害群はほぼ正常者 の場合と等しいが, 咱粘膜性, 混合性, 中枢性嗔覚障害 群では相違が認められた。すなわ方，嗅粘膜およびそれ より中枢側の障害にては検知, 認知域值の差が大である か，算出不能であった。

4) 呼吸性嗅覚障害は, 嗅部に達する嗅素の物理的障 害によるものであるが，実験的呼吸性嗅覚障害よりも検 知域值と認知域值との差がやや大きい，嗅部以外に鼻腔 内にも嗅素に反态する部のあることが推定される。

5 ) 嗅粘膜性嗅覚障害, 中枢性嗅覚障害に検知, 認知 域値の差の大きい症例が認められた。これは嗅細胞の嗅 神経の病態生理学的な現象と考えられる。嗅細胞を含む 嗅神経が退化, 消失した場合には㖵覚は廃絶する。検知 域值が测定された場合は嗅細胞, 㖵神経の残存か, 副嗅 覚系一の反応と考える。「ニオイ」でないものも検知域 值として測定する可能性があるため, 認知域值を重視す べきである。

以上より，障害部位別にて㖵賞化差異があるため, 基 準嗅力検查にても嗅覚障害部位をある程度推定すること ができると信ずる。

\section{参考文献}

1) 豊田文一：嗅覚検査のための基準臭と梌查方式の研 究. 47 年度文部省研究報告集録（医学括上び薬学 I) 231-240, 1973.

2) 高木貞敬：鮕覚テストと㖵（覚能）力の量的表現 耳喉 $43: 383-385,1971$.

3) 長野治辟：嗅粘膜の内視鏡所見飞関す研究 日耳 楀 $80: 241-248,1977$.

4) Yoshida $M$ : Studies in psychometric classification of ordors (6) Japanese Psychological Research $14: 70-86,1972$.

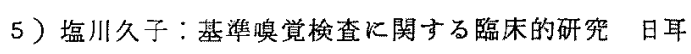
舅 $78: 1258-1275: 1975$.

6）福島淑子：嗅覚障害の治㙩法 日耳鼻 $81: 36-44$, 1978.

7) Henkin RI: The definition of primary and accessory areas of olfaction as the basis for classification of decreased olfactory accuity. Olfaction and tast II 235-245, pergamon press, London, 1967.

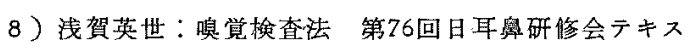
卜 6-10, 1975.

稿を終えるに当たりここ指導，ご校閲を晹った岡本途 也教授ならびに終始ご指導の学を惜しまなかった浅賀 英世助教授はじめ昭和大学耳且盶喉科学教室嗅觉班の諸 先生に梁甚の謝意を表す。

\begin{tabular}{|c|c|c|}
\hline & （原稿受付 昭和53.3.24日) & \\
\hline 別刷請求先 & 厂142 東京都品川区旗の台1-5-8 & 昭和大 \\
\hline
\end{tabular}

